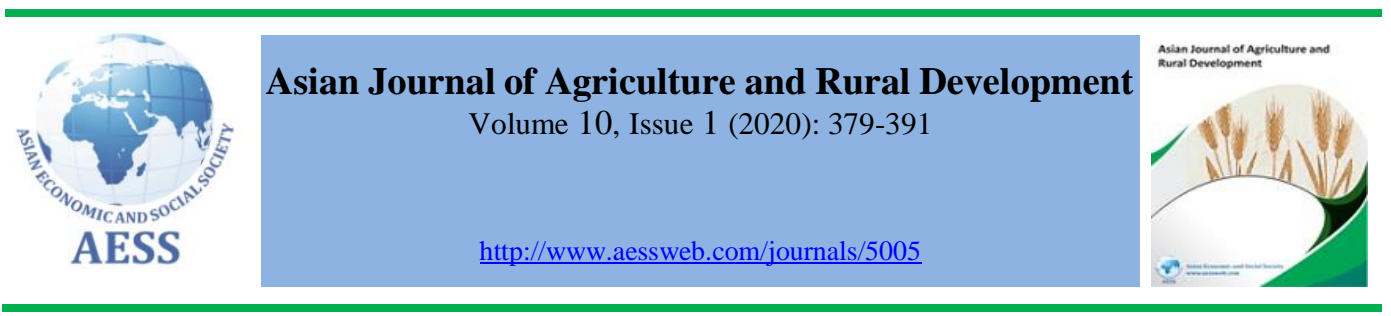

\title{
ECONOMIC ANALYSIS OF HIGH-DENSITY APPLE PLANTATION SCHEME IN JAMMU AND KASHMIR
}

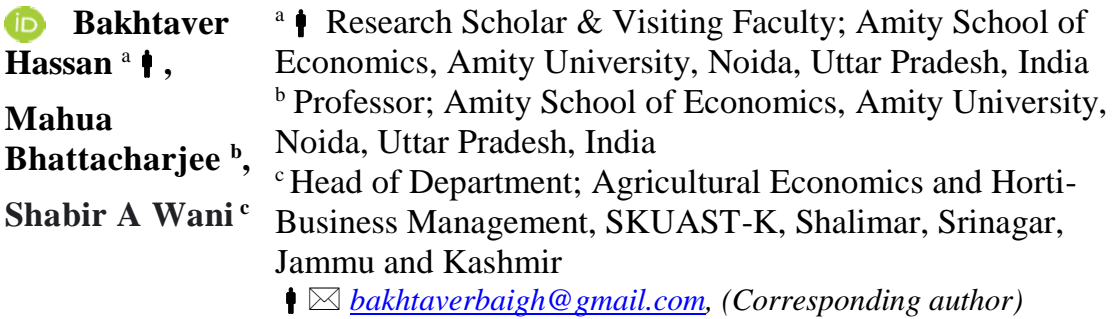

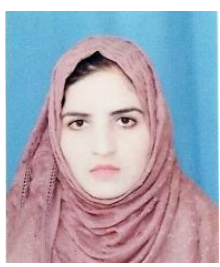

Corresponding author

\section{ARTICLE HISTORY:}

Received: 12-Mar-2020

Accepted: 13-May-2020

Online Available: 15 -Jun2020

\section{Keywords:}

Horticulture,

Net present value,

Yield,

Kashmir,

Break-even year,

Net revenue,

Profitability

\begin{abstract}
This paper evaluates the performance of the high-density apple plantation scheme, launched in 2016 in Jammu \& Kashmir, India to boost both productivity and production of apples, amidst the stagnancy witnessed in the sector. Primary data was collected from apple farmers in two districts, Kulgam and Pulwama. The qualitative techniques were used to estimate the yield, establishment cost, and break-even year of the different orchard densities. Multiple Regression Analysis and multivariate statistical techniques were used for yield-forecasting and estimation of Net Present Value and Internal Rate of Return respectively. The results show that the yield has increased by two-five times than the traditional orchards. Break-even year for different densities without government was found to be 6-years while with government support it went down to just 4-5 years. Net Present Value and Internal Rate of Return, further substantiate high-profitability and early returns in these orchards. Further, it was concluded that the government subsidy provides significant support to the farmers in two main densities - 2200trees/hectare and 3300trees/hectare. Thus, the government should broaden the scheme and make it more inclusive for the overall development of the sector.
\end{abstract}

\section{Contribution/ Originality}

The study provides a foundational pathway to research regarding the economic analysis of high-density orchards in Jammu \& Kashmir. It is the first study that deals extensively with the present and prospects of the high-density orchards in the region. The results of the paper suggest that the government should be more inclusive and provide due support to the farmers for establishing these highly profitable orchards.

DOI: 10.18488/journal.1005/2020.10.1/1005.1.379.391

ISSN (P): 2304-1455/ISSN (E):2224-4433

How to cite: Bakhtaver Hassan, Mahua Bhattacharjee and Shabir A Wani (2020). Economic analysis of high-density apple plantation scheme in Jammu and Kashmir. Asian Journal of Agriculture and Rural Development, 10(1), 379-391.

(C) 2020 Asian Economic and Social Society. All rights reserved. 


\section{INTRODUCTION}

Agriculture continues to be the dominant sector in the Union Territory of Jammu and Kashmir. Around $70 \%$ of the population of the Union Territory is directly or indirectly dependent on agriculture (Shaheen et al., 2019). In terms of GSDP- Gross State Domestic Product, agriculture contributes $17.2 \%$ compared to the national contribution of $15.5 \%$ in 2019-20 (Government of Jammu and Kashmir, 2017a). The growth-rate of Agriculture in the Union Territory was $24.6 \%$ in 2015-16 and 8.4\% in 2016-17 respectively, while the national average has been hovering around $2.9 \%$ (Government of Jammu and Kashmir, 2017b).

Horticulture is the most important driver of agricultural growth rate in the Union Territory and contributes nearly $40 \%$ to the total output from agriculture (Malik, 2013). It is regarded as a sunrise sector in the region with nearly seven lakh families and 33 lakh people directly or indirectly involved in the sector (Jha et al., 2019, Rather et al., 2013). It is one of the thrust areas of the economy of the Union Territory.

Apple significantly contributes nearly $60 \%$ to the total horticultural output in Jammu and Kashmir. About $50 \%$ of the area is covered under the apple and there is a 6 percent growth in the annual production of the crop (Government of Jammu and Kashmir, 2017a). In 2018-19, the total production of apple from the Union Territory was 19 lakh tonnes which were nearly $77 \%$ of the total production of the country as a whole (Horticulture at Glance 2018, National Horticulture Board). In terms of economy, the sector is ever-increasing with an annual export of more than 70 billion from the fruits alone (Naqash et al., 2019).

Horticulture has tremendously grown in Jammu and Kashmir from the last five decades. The area and production of the horticultural crop have consistently increased by three-fold (300\%) and tenfold $(985 \%)$ respectively (Table 1$)$. In the meantime, the productivity has witnessed a four-fold jump which is higher than the two-fold national average. While the acreage under Apple has witnessed a fall from $55-56 \%$ to $48 \%$, however, the production has increased by manifolds (Hanan, 2015).

Table 2, clearly depicts that the productivity or the yield per hectare of Jammu and Kashmir has been higher than the national average. For instance, in Apple alone, the UT's average yield is 11.43 tonnes/hectare which is higher than the national average of 9.73 tonnes/hectare. Himachal Pradesh which contributes $21 \%$ to the total production, has an average yield of 6tonnes/hectare which is two-time lower than yield per hectare of Jammu and Kashmir (Malik and Choure, 2014). In Walnut too, there is a large difference in productivity between Jammu and Kashmir and the second largest producing state-Uttarakhand (Taili, 2014). However, when we compare this average yield of Jammu and Kashmir and India as a whole with that of the World Average, we see a considerable difference of around 40 tonnes/hectare. The productivity of developed countries in temperate zones for instance Italy, Netherlands, New Zealand near almost 70-75tonnes/hectare (Robinson et al, 2004). 
Table 1: Growth trend of horticultural crops in Jammu and Kashmir

\begin{tabular}{|c|c|c|c|c|c|c|c|c|c|}
\hline & \multicolumn{3}{|c|}{ 1974-75 } & \multicolumn{3}{|c|}{$2000-01$} & \multicolumn{3}{|c|}{ 2018-19 } \\
\hline & $\begin{array}{c}\text { Area } \\
\text { (hectares) }\end{array}$ & $\begin{array}{c}\text { Production } \\
\text { (Metric tonnes) }\end{array}$ & $\begin{array}{c}\text { Productivity } \\
\text { (tonnes/ha) }\end{array}$ & $\begin{array}{c}\text { Area } \\
\text { (hectares) }\end{array}$ & $\begin{array}{c}\text { Production (Metric } \\
\text { tonnes) }\end{array}$ & $\begin{array}{c}\text { Productivity } \\
\text { (tonnes/ha) }\end{array}$ & $\begin{array}{c}\text { Area } \\
\text { (hectares) }\end{array}$ & $\begin{array}{c}\text { Production } \\
\text { (Metric tonnes) } \\
\end{array}$ & $\begin{array}{c}\text { Productivity } \\
\text { (tonnes/ha) }\end{array}$ \\
\hline Apple & 46189 & 190452 & 4.12 & 88149 & 751310 & 8.52 & 164742 & 1882319 & 11.43 \\
\hline Cherry & 654 & 510 & 0.78 & 2368 & 5293 & 2.24 & 2713 & 11789 & 4.35 \\
\hline Pear & 2296 & 7655 & 3.33 & 9169 & 31324 & 3.42 & 13945 & 86034 & 6.17 \\
\hline Almond & 9361 & 1525 & 0.16 & 18059 & 10901 & 0.60 & 5588 & 10326 & 1.85 \\
\hline Walnut & 13246 & 10520 & 0.79 & 59900 & 83399 & 1.39 & 84777 & 279422 & 3.30 \\
\hline Others & 10740 & 5502 & 0.51 & 41394 & 49573 & 1.20 & 72334 & 76453 & 1.06 \\
\hline Total & 82486 & 216164 & 1.62 & 219039 & 931800 & 2.89 & 344099 & 2346343 & 4.69 \\
\hline
\end{tabular}

Source: Directorate of Horticulture, Jammu and Kashmir, 2019

Table 2: Comparative yields of horticultural crops in 2018-19. (tonnes/hectare)

\begin{tabular}{|c|c|c|c|}
\hline Crop & JK Average Yield & National Average & World Average \\
\hline Apple & 11.43 & 9.73 & $55-63$ \\
\hline Pear & 6.17 & 5.3 & $55-60$ \\
\hline Peach & 2.16 & 3.6 & $15-20$ \\
\hline Cherry & 4.35 & 3.03 & $9-11$ \\
\hline Almond & 1.85 & 0.7 & $3-5$ \\
\hline Walnut & 3.3 & 1.64 & $6-8$ \\
\hline Others & 1.06 & 1.63 & $5-7$ \\
\hline
\end{tabular}

Source: Directorate of Horticulture, Jammu and Kashmir, 2019. FAO, 2019. Horticulture at a Glance, National Horticulture Board, India, 2018-19 
The recent rollout of the High-Density Apple Plantation scheme by the Department of Horticulture, Jammu and Kashmir is extremely important to increase productivity and production of Apples in Jammu and Kashmir. In Himachal Pradesh, the production and quality of apples have improved substantially (Singh et al., 2012). Intensive orcharding is the most efficient technology evolving in horticulture. The early gestation period, high-quality produce, and higher productivity help the farmers to generate high returns (Badiu et al., 2015). The yield per hectare increases at least twice than that in traditional orchard systems (Singh et al., 2012). Further, the farmer has the choice to opt for different densities ranging from 1500 trees/hectare to 5000 trees/hectare. There exists a linear relationship between the cost, yield, and the density of the orchard. Although higher densities are capital-intensive upfront the benefit-cost ratio in the long-term is very high (Cahn and Goedegebure, 1992). With high-density orchards, the farmers' net-return is substantially higher and is an effective tool to improve total horticultural output (Meland, 2005, Sansavini et al., 1980). Even in mango cultivation, high-density orchards provide increasingly high productivity and therefore better returns in the market (Kerutagi et al., 2017). Jammu and Kashmir offers favourable agri-climate conditions for the development of High-Density Apple Orchards This would result in an increase in the production and productivity of the crop and attract low-yield rice cultivating farmers to high-density apple orchards (Kumar et al., 2012).

\subsection{Objectives}

1. To make a fair assessment of the performance of the high-density apple plantation scheme in Jammu and Kashmir.

2. To compute the profitability of the high-density orchard combinations and its relative feasibility for large-scale development in Jammu and Kashmir.

\section{DATA AND METHODOLOGY}

\subsection{Sample size and data collection}

Primary data was collected from a sample of farmers who became the beneficiaries of the HighDensity Apple Plantation Scheme. According to Horticulture Department, Jammu \& Kashmir (2016-17), 95 percent of the farmers who opted for the scheme were from Pulwama and Kulgam, District of Jammu and Kashmir, India; therefore, these two districts were selected. A ground-level survey was conducted to identify the beneficiaries/farmers from different villages in these districts during December 2019 and January 2020. During the survey, 37 farmers from 15 villages in Kulgam District and 48 farmers from 18 villages in Pulwama District were identified, who adopted the scheme in the first year. Damhal, Frisal and Mohammadpura villages from Kulgam District and Chakoora, Chatapora, Rajpora, Heff, Dadsara, and Chersoo villages from Pulwama District were the most prominent villages where the scheme was widely adopted. Finally, data were collected through a personal response questionnaire from these 85 farmers/beneficiaries from the two districts.

The farmers were divided into four major groups based on their land-size and the corresponding tree-density was recorded (Table 3). Four main densities of orchards were found in the region. An important correlation was developed between land-sizes of the farmers and the tree-densities. Data shows that almost 68.23 percent of the farmers chose tree-density of 2200trees/hectare, 18.82 percent chose 3300 trees/hectare, and 8.2 percent of farmers chose 4400 trees/hectare. Out of the seven farmers opting for 4400 trees/hectare, 85.7percent farmers belonged to small and marginal category $(<1$ hectare $)$. 
Table 3: Farm size of the sampled orchardists along with their respective choices

\begin{tabular}{|c|c|c|c|c|c|}
\hline Size of Farm & $\begin{array}{l}\text { Number } \\
\text { of Farms }\end{array}$ & $\begin{array}{c}\text { Percentage } \\
\text { with } 1100 \\
\text { Trees/Ha } \\
(3 \mathrm{mx} 3 \mathrm{~m})\end{array}$ & $\begin{array}{l}\text { Percentage of } \\
\text { farmers } 2200 \\
\text { Trees/ha }(3 \mathrm{~m} \\
\quad \text { x } 1.5 \mathrm{~m})\end{array}$ & $\begin{array}{c}\text { Percentage of } \\
\text { Farmers } 3300 \\
\text { Trees/ha }(3 \mathrm{~m} \\
\text { x 1m) }\end{array}$ & $\begin{array}{c}\text { Percentage of } \\
\text { Farmers } \\
\text { with } 4400 \\
\text { Trees/ha }(2.25 \\
\text { x } 1 \mathrm{~m}) \\
\end{array}$ \\
\hline $\begin{array}{l}\text { Marginal }(<0.1 \\
\text { hectare })\end{array}$ & $20(23.53)$ & 5 & 70 & 20 & 5 \\
\hline Small (0.1-1 hectare) & $40(47.05)$ & 7.5 & 65 & 15 & 12.5 \\
\hline $\begin{array}{l}\text { Medium (1-2 } \\
\text { hectares) }\end{array}$ & $21(24.7)$ & 0 & 71.43 & 23.80 & 4.77 \\
\hline Large ( $>2$ hectares) & $04(4.7)$ & 0 & 75 & 25 & 0 \\
\hline Total & 85 & 4.7 & 68.23 & 18.82 & 8.2 \\
\hline
\end{tabular}

parenthesis denotes percent

Source: Field survey, 2019-20

\subsection{Yield and production data}

Primary and secondary data were collected to estimate the yield per hectare. Data regarding the annual production of apple boxes were collected from the respondents. Data for weight and price was collected from the Horticulture Department, Jammu and Kashmir. The price of each box depends on the particular Grade of Apple. Grade A, B and C apples are priced at $0.8 \mathrm{USD} / \mathrm{kg}$ (60 INR/kg), $0.53 \mathrm{USD} / \mathrm{kg}$ (40 INR/kg) and $0.32 \mathrm{USD} / \mathrm{kg}$ (24 INR/kg), respectively (NAFED, 2019). The gross weight of each box is $18 \mathrm{kgs}$ while the net weight is $16 \mathrm{kgs}$. Using mean and standard deviation, the average price of each box was taken as $9.33 \mathrm{USD} /$ box (700 INR/box). Yield and total production from the sample were therefore calculated. Yield per hectare was taken as tonnes/hectare of the four different densities of the orchards.

\subsection{Yield forecasting}

Different models in machine learning are used to forecast the crop yield. Regression analysis was used to estimate the yield of the crop posts in the fifth year. The first few years of the apple orchards have shown a proportionate development of the yield compared to earlier studies made by Cahn and Goedegebure (1992) in the Netherlands. Primary Data was collected from the respondents while the secondary data was collected from the Department of Horticulture, Jammu and Kashmir to form an organized dataset. The dataset included data on irrigation, rainfall, acreage under the orchards, input supplies like pesticides, fertilizers, manure, quality of the rootstock, and the soil-health. Chipanshi et al. (2015) considered a linear regression model for the estimation of crop-yield forecasting in Canada.

The model in which the value of R-square is higher while the value of MPPE-Mean Percentage Prediction Error and RMSE- Root Mean Square Error is lower, is considered the most accurate model for forecasting the crop yield (Shastry et al., 2017). Multiple Regression Model was used in forecasting the yield for 20 years (R-Squared=0.92).

\subsection{Establishment and maintenance}

Primary Data was used to compute the total establishment cost which is one of the important parameters in the development of the orchards. The cost analysis of the establishment of the orchards helps the farmers to plan economically. In this regard, since the scheme had an inbuilt subsidy clause of 50 percent to the farmers in two major densities- 2200trees/ha and 3300trees/ha. It is therefore important for the government too, to analyse the establishment cost.

The total cost of the orchard majorly includes: 
a. Non-Harvest Variable Cost which includes land development, drip-irrigation, plant-material, fertilizers, pesticide, and development of the trellis system.

b. Harvest Variable Cost which includes Harvesting, Picking, Sorting, Transportation, and Supervision.

c. Fixed Cost which includes Land Costs (Rental Value), Depreciation, and Interest Cost.

An important feature of the analysis is that interest cost in the two main orchard combinations (2200trees/ha and 3300trees/ha) kicks in the fourth year because of the government support in the first three years. Therefore, Net-Cost computed in the study incorporates this important factor.

\subsection{Break-even year analysis (payback period)}

Break-Even Year Analysis was done to estimate the year in which the accumulated revenue of each orchard combination will be equal to the accumulated cost (establishment and maintenance cost until that year). The purpose of the break-even analysis is to assess how early the value of production kicks in so that the farmer gaining net profit (Cahn and Goedegebure, 1992). Postbreak-even year, the farmer starts profiting from his/her orchard system. The fixed costs remain constant while only the variable costs are varied for the calculation of the break-even year. Breakeven Analysis is very useful as a management tool, as it is simple to apply and understand and readily applicable in farm management. An investment with early break-even year is the most desirable one, however, there are shortcomings in this, as early break-even year (payback period) may also come with lower long-term returns. Therefore, the Net Present Value and Internal Rate of Return is used to analyse the long-term impact of the likely investment in the orchards.

\subsection{Net present value and internal rate of return analysis}

Net Present Value is simply the net cash inflow or the revenue generated over a while from an investment. It is therefore used to determine the profitability of an investment. Higher the value of Net Present Value (NPV), profitable the investment (Ivey, 1990).

Internal Rate of Return (IRR), also determines the profitability of the investment. It simply estimates the expected rate of growth of an investment. It is more useful than the CAGRCompound Annual Growth Rate as it takes into account all the cash inflows over the period while CAGR takes into account the initial and final inflows only. Both NPV and IRR are extremely useful for the assessment of the orchard combinations. While NPV gives the amount earned by the farmers over the discount rate (usually the interest rate), the IRR gives the actual percentage return of the farmers' investment.

The formula for Net Present Value,

$$
N P V=\sum_{n=1}^{k} \cdot \frac{(\text { Total Revenue }- \text { Total Cost })_{\cdot n}}{(1+d)^{n}}
$$

Where " $\mathrm{k}$ " is expected life of the orchards, " $\mathrm{n}$ " is the time period for the analysis, " $\mathrm{d}$ " is the appropriate discount rate and (Total Revenue- Total Cost) is the net accumulated revenue in the time period, "n."

The formula for Internal Rate of Return

$$
0=N P V=\sum_{n=1}^{k} \frac{(\text { Total Revenue }- \text { Total Cost })_{n}}{(1+I R R)}-\text { Total Cost }
$$

Where, "k", is the expected life of the orchards, and NPV is the Net Present Value of the different orchard combinations. 


\section{RESULTS AND DISCUSSION}

\subsection{Yield and production}

Yield per hectare or productivity is one of the most important parameters for assessing the performance of the crops. Table 3, shows that the yield per hectare in all the orchard combinations increases linearly with time from the second year (Year 1). In the lowest tree-density orchard, the yield per hectare was 0.64 tonnes/hectare in the first year which increased to 21.76 tonnes/hectare in the fourth year. In orchards with density 2200 trees/hectare, the yield has increased from 0.912 to 29.6 tonnes/hectare during the same time. Similarly, the yield in the higher-density orchards has increased substantially giving a push to the sector. The productivity is increasing proportionately which is consistent with Cahn and Goedegebure (1992) analysis of the high-density orchards in the Netherlands.

Table 4: Yield per hectare of different tree-densities

\begin{tabular}{lcccc}
\hline YEAR & $\mathbf{1 1 0 0}$ & $\mathbf{2 2 0 0}$ & $\mathbf{3 3 0 0}$ & $\mathbf{4 0 0 0}$ \\
\hline YEAR 1 & & & & \\
YEAR 2 & 0.64 & 0.912 & 1.104 & 1.6 \\
YEAR 3 & 11.824 & 19.936 & 23.296 & 35.12 \\
YEAR 4 & 21.76 & 29.6 & 36.56 & 49.552 \\
YEAR 5 & 25.968 & 36.56 & 48.288 & 59.344 \\
YEAR 6 & 31.648 & 45.44 & 52.96 & 63.792 \\
YEAR 7 & 40.08 & 52.864 & 60.704 & 72.304 \\
\hline
\end{tabular}

Source: Field Survey, 2019-20

The orchards are in their fifth year with three years of production and therefore have not reached the full potential. The yield of upcoming years from fifth to seventh comes to be consistent with the current development based on the input parameters. In the seventh year, the yield for orchards of density 3300trees/hectare will be 60.7 tonnes/hectare, this is comparable with the yield in developed economies.

Table 5, shows the number of apple boxes produced from the given sample under study. The production has increased considerably in all the tree-densities. When compared with the analysis done by Shaheen et al. (2019), in the fourth year of these orchards the number of boxes harvested per hectare is higher than the production of a full-grown traditional apple orchard in the region. The production will reach $52784 \mathrm{kgs}$ and $60704 \mathrm{kgs}$ in 2200 trees/hectare and 3300 trees/hectare respectively which is three-four times higher than that of the traditional apple orchard systems.

Table 5: Number of apple boxes produced in different densities (trees/hectare)

\begin{tabular}{lcccc}
\hline Tree-Density (trees/ha) & $\mathbf{1 1 0 0}$ & $\mathbf{2 2 0 0}$ & $\mathbf{3 3 0 0}$ & $\mathbf{4 4 0 0}$ \\
\hline Year 1 (2016) & 20 & & & \\
Year 2 (2017) & 739 & 1246 & 60 & 100 \\
Year 3 (2018) & 1360 & 1850 & 1456 & 2195 \\
Year 4 (2019) & 1623 & 2285 & 2285 & 3097 \\
Year 5 (2020) & 1978 & 2840 & 3018 & 3709 \\
Year 6 (2021) & 2505 & 3304 & 3310 & 3987 \\
Year 7 (2022) & 8225 & 11565 & 3794 & 4519 \\
Total Boxes & & 13923 & 17607 \\
\hline
\end{tabular}

Source: Field survey, 2019-20

Gross Weight of each box $=18 \mathrm{kgs} .$, Net weight of each box $-16 \mathrm{kgs}$ 


\subsection{Establishment and maintenance cost}

The establishment cost shows a linear relation with the tree-density (Figure 1). This cost majorly includes non-harvest cost and fixed costs like land rent and depreciation of the machinery. In higher-density orchards, there is a slight dip in the establishment cost, possibly because of same fixed costs for all the orchards as well as due to discount rates that apply in procuring material for the development of the orchards. This trend is also consistent with the study done by Cahn and Goedegebure (1992).

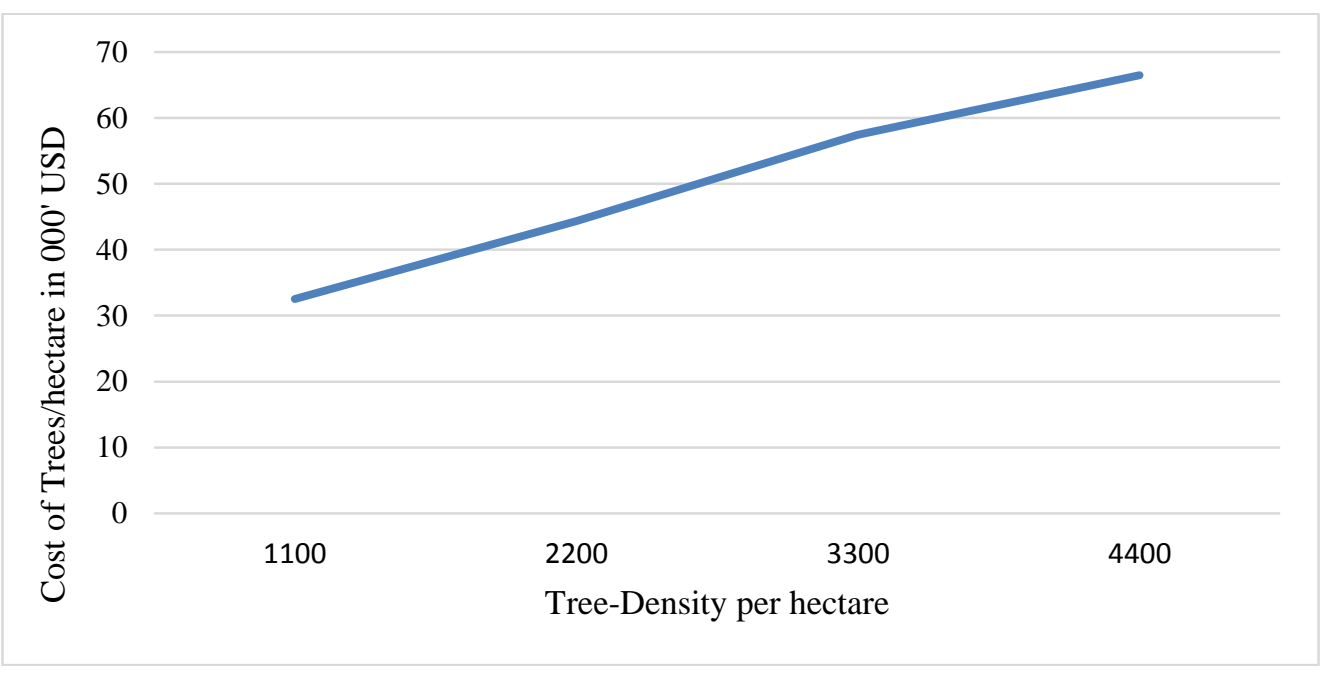

Figure 1: Establishment Cost with respect to tree-density

The maintenance cost varies according to the orchard density, as the supervision and tree-training costs increase with an increase in the tree-density. The harvesting and transportation cost increases with the increase in the production for each orchard combination with time. These costs show a linear relationship with the tree-density of the orchards. The profitability of the orchard combinations depends on the difference between the total costs and the total revenue. Higher the economic efficiency of the orchards, the higher the profitability. Among small and marginal farmers, the upfront establishment cost is therefore an important parameter to assess how they adopt the new high-density scheme. For instance, for a marginal farmer $(<0.1$ hectares $=2$ kanals $)$, the total upfront cost ranges from 3.2 thousand ${ }^{1}$ USD (equivalent to 0.24 million INR) too 6.8 thousand USD (0.51 million INR) which is extremely high. But the same cost when subsidized might seem favourable to the farmer as he pays just $50 \%$ of the total establishment cost.

\subsection{Break-even year analysis}

The farmers start harvesting apples only in the second year of their orchards (Table 6). The value of production or the revenue in the second year of the orchards is very low, however, the early gestation period is an important outcome here. Different orchard combinations with their different yields (Table 4) have different values of production annually. For 1100trees/hectare orchards, the farmers earn 6.8 thousand USD (0.51 million INR) in the third year, it is 11.62 thousand USD $(0.87$ million INR), 12.59 thousand USD (1.019 million INR) and 0.48 thousand USD (1.536 million INR) for 2200 trees/ha, 3300 trees/ha and 4400 trees/ha respectively. This increases to 12.67 thousand USD ( 0.95 million INR), 17.28 thousand USD (1.296 million INR), 21.33 thousand USD (1.6 million INR) and USD 28.89 thousand (2.167 million INR) for 1100 trees/ha, 2200trees/ha, 3300 trees/ha and 4400 trees/ha respectively in the fourth year. Therefore, the value of production per hectare has increased significantly for the farmers from 9.36 thousand USD (0.702 million INR) per hectare in developed traditional orchards (Naqash et al., 2019) to 12.73 to 22.92 USD

${ }^{1} 1 \mathrm{USD}=75$ INR (approximate exchange rate in 2020) 
(0.955- 2.196 million INR) in only the fourth year of the different orchard combinations in the high-density orchards.

Break-Even Year is crucial for the farmers in the region. As the establishment cost is already high, so the farmers demand early and higher returns to repose their faith in modern-day farming. Table 6 , shows the net accumulated cost in the first four years of the orchards. Net accumulated cost is the total cost excluding the total revenue earned by the farmer during the four years (Net Accumulated Cost $=$ Total Cost - Total Revenue). The different combinations of the orchards warrant different treatment in the analysis, as two combinations (2200trees/density and 3300trees/density) are supported by the government.

Table 6: Net Accumulated Cost in the first four years of the Orchards (in thousand USD)

\begin{tabular}{|c|c|c|c|c|c|c|c|c|}
\hline \multirow{2}{*}{ Tree density } & \multicolumn{2}{|c|}{1100 trees/ha } & \multicolumn{2}{|c|}{2200 trees/ha } & \multicolumn{2}{|c|}{3300 trees/ha } & \multicolumn{2}{|c|}{4400 trees/ha } \\
\hline & Cost & Revenue & Cost & Revenue & Cost & Revenue & Cost & Revenue \\
\hline \multirow{2}{*}{ Year 1} & 32.56 & & 44.36 & & 57.43 & & 66.5 & \\
\hline & $(2.442)$ & & (3.327) & & 4.307 & & (5.054) & \\
\hline \multirow{2}{*}{ Year 2} & 2.2 & 0.37 & 4.53 & 0.52 & 5.75 & 0.64 & 6.48 & 0.933 \\
\hline & $(0.165)$ & $(0.028)$ & $(0.34)$ & $(0.039)$ & $(0.431)$ & $(0.048)$ & $(0.486)$ & (0.07) \\
\hline \multirow{2}{*}{ Year 3} & 2.88 & 6.8 & 5 & 11.63 & 6.1 & 13.58 & 7.72 & 20.48 \\
\hline & $(2.16)$ & $(0.51)$ & $(0.375)$ & $(0.872)$ & $(0.458)$ & (1.019) & $(0.579)$ & $(1.536)$ \\
\hline \multirow{2}{*}{ Year 4} & 3.21 & 12.67 & 7.37 & 17.28 & 8.18 & 21.32 & 10.04 & 28.89 \\
\hline & $(0.241)$ & $(0.95)$ & $(0.553)$ & $(1.296)$ & $(0.614)$ & $(1.599)$ & $(0.753)$ & $(2.167)$ \\
\hline \multirow{2}{*}{ Total } & 40.85 & 19.84 & 61.27 & 29.43 & 77.47 & 35.55 & 91.63 & \\
\hline & (3.064) & (1.488) & $(4.595)$ & (2.207) & $(5.81)$ & (2.66) & $(6.872)$ & $(3.1 / 3)$ \\
\hline \multicolumn{3}{|l|}{ Subsidy } & \multicolumn{2}{|c|}{$21.33(1.6)$} & \multicolumn{2}{|c|}{$42.63(3.2)$} & & \\
\hline Net & \multirow{3}{*}{\multicolumn{2}{|c|}{$21.01(1.576)$}} & \multirow{3}{*}{\multicolumn{2}{|c|}{$10.5(0.788)$}} & \multirow{3}{*}{\multicolumn{2}{|c|}{$-0.75(-0.056)$}} & \multirow{3}{*}{\multicolumn{2}{|c|}{$41.32(3.099)$}} \\
\hline Accumulated & & & & & & & & \\
\hline Cost & & & & & & & & \\
\hline
\end{tabular}

Parenthesis denotes cost in million Indian Rupees

Source: Field survey, 2019-20. Price $=$ USD 9.33/box $=700 \mathrm{INR} / \mathrm{box}=18 \mathrm{kgs} / \mathrm{box}$

Table 8, shows the break-even year of different orchard combinations. Without government support, Year 6 is the break-even year for all the orchard combinations. However, the government support in two orchard combinations proves a major difference in the net accumulated cost in the fourth year. Orchardists with a density of 3300 trees/hectare in their farms are given the support of 42.63 thousand USD upfront subsidy as a result of which the orchardist earns profit in the fourth year only of their orchard. The break-even year for this orchard combination is four years with support from the government. This means 18.82 percent of farmers in the region, (Table 3) have already started earning profits in the fourth year (2019). Similarly, for another 68.23 percent farmers with orchards, the break-even year was Year 5.

\subsection{Net present value and internal rate of return analysis}

The regression analysis done, provided a forecast of yield in different orchard combinations (different densities), for twenty years. This yield was estimated to be dependent on certain important variables like annual rainfall, price of the produce (which was kept constant for the period), fertilizer, and soil health. Table 7 , gives the yield per hectare for the 20 -year period which was used to estimate the Net Present Value and Internal Rate of Return Analysis. The accuracy of the regression is high as the R-squared is 0.977 . 
Table 7: Expected yields in bins per acre for the vertical axis variety/rootstock combinations $($ Yield $=$ tonnes $/$ hectare $)$

\begin{tabular}{lcccc}
\hline Tree density (trees/ha) & $\mathbf{1 1 0 0}$ & $\mathbf{2 2 0 0}$ & $\mathbf{3 3 0 0}$ & $\mathbf{4 4 0 0}$ \\
\hline Year 7 & 40.08 & 52.86 & 60.704 & 72.304 \\
Year 8 & 42.48 & 55.76 & 67.2 & 76.7 \\
Year 9 & 42.16 & 56.18 & 68.86 & 77.69 \\
Year 10 & 41.76 & 56.98 & 68.12 & 77.26 \\
Year 11-20 & 40.91 & 56.12 & 67.65 & 76.19 \\
\hline
\end{tabular}

Source: Authors' own analysis

Accumulated net cost in the seventh year for different orchard combination gives an optimistic perspective of the performance of the high-density orchards in the region. The net accumulated cost/revenue in the seventh year, therefore, for 1100 trees/hectare orchard is 23.58 thousand USD (1.769 million INR), for 2200trees/hectare it is 24.4 thousand USD (1.83 million INR) without government support and 45.73 thousand USD (3.43 million INR) with government support. This is very significant for the farmers as it pushes the net revenue of the farmers by over $300 \%$ in the seventh year of the production than the traditional orchard system (Naqash et al., 2019).

Net Present Value and Internal Rate of Return enables us to understand the profitability of the orchard combinations. At the end of the $7^{\text {th }}$ Year, the Net Present value is highest for the lowestdensity orchard (1100 trees/hectare) and lowest for the highest density orchard (4400trees/hectare) (Table 8). The reason is that the establishment cost is high upfront with respect to the high-density orchards. Establishment cost for orchards of density 1100trees/hectare and 4400trees/hectare is 32.26 thousand USD (2.42 million INR) and 67.2 thousand USD (5.04 million INR) respectively. Similarly, the Internal Rate of Return is highest for the lowest density orchard and vice-versa. A high internal rate of return in the lowest density orchard means that the "profitability rate of return" for the investment is higher and earlier than the rest.

Table 8: Economics of different densities of apple orchards

\begin{tabular}{lcccccc}
\hline $\begin{array}{l}\text { Accumulated } \\
\text { Density } \\
\text { Trees/Hectare) }\end{array}$ & $\begin{array}{c}\text { 7 Year Net } \\
\text { Cost (000 } \\
\text { USD) }\end{array}$ & $\begin{array}{c}\text { Break-Even } \\
\text { Year }\end{array}$ & $\begin{array}{c}\text { Net } \\
\text { Present } \\
\text { Value at 7 } \\
\text { Years (000 } \\
\text { USD) }\end{array}$ & $\begin{array}{c}\text { Net Present } \\
\text { Value at 20 } \\
\text { Years (000 } \\
\text { USD }\end{array}$ & $\begin{array}{c}\text { Internal } \\
\text { Rate of } \\
\text { Return @ } \\
\text { 7 Years }\end{array}$ & $\begin{array}{c}\text { Internal } \\
\text { Rate of } \\
\text { Return @ } \\
\text { 20 Years }\end{array}$ \\
\hline 1100 & -23.57 & Year 6 & 41.45 & 150.67 & $19 \%$ & $35 \%$ \\
2200 & $-24.4(-45.73)$ & Year 6 (Year 5) & $24.4(45.73)$ & $160.72(182)$ & $10 \%(26 \%)$ & $29 \%(42 \%)$ \\
3300 & $-27.92(-55.92)$ & Year 6 (Year 4) & $26(54)$ & $175.46(203.46)$ & $8 \%(25 \%)$ & $29 \%(40 \%)$ \\
4400 & -41.59 & Year 6 & 17.6 & 209.6 & $11 \%$ & $27 \%$ \\
\hline
\end{tabular}

Note: 1 United States Dollar $=75$ Indian Rupees (Exchange rate, 2020)

Discount Rate $-9.5 \%$, parenthesis indicates the break-even year and NPV and IRR with government subsidy. Price of box $=9.33 \mathrm{USD} / \mathrm{box}$ or INR700/box, which is kept constant for the 20 years. (Mean price).

But the case reverses as we analyse the Net Present Value at the $20^{\text {th }}$ Year (Table 8). The highest density orchard(4400trees/hectare) has the highest Net Present Value at 209.6 thousand USD (15.72 million INR). Net Present Value at the $20^{\text {th }}$ Year of orchards of densities 2200trees/ha and $3300 \mathrm{trees} / \mathrm{ha}$ is at 160.72 thousand USD (12.054 million INR) and 175.46 thousand USD (13.16 million INR) respectively. However, for the lowest density orchard, NPV is 150.93 thousand USD (11.32 million INR). Therefore, Net Present Value increases with an increase in the tree-density per hectare, implying that the highest-density orchards are the most profitable ventures even when their establishment cost is high. Internal Rate of Return, however, decreases with an increase in the treedensity (Table 8). Lowest-density orchard has a high internal rate of return (35 percent), while the highest-density orchard has the lowest internal rate of return (27 percent). An important conclusion 
drawn from this is that the higher-density orchards see a slow return on their investment as compared to the low-density orchards but the overall profitability, as well as value, is significantly higher in the higher-density orchards. Thus, making them the best long-term investment choice for the farmers.

With government support for two orchard combinations, the Net Present Value and Internal Rate of Return also shift positively. Net Present Value in orchards with densities 2200trees/hectare is 45.73 thousand USD (3.43 million INR) and 182 thousand USD (13.65 million INR) for 7-year and 20year period respectively. Internal Rate of Return also increases from 10 percent to 26 percent in the 7 years and 29 percent to 42 percent in the 20 years. Similarly, for the orchards with density 3300 trees/hectare, NPV for 7-and 20-year period is 54 thousand USD (4.05 million INR) and 203.46 thousand USD (15.26 million INR). The internal rate of return also sees a change from 8 to 25 percent and 29 to 40 percent in a 7 -and 20 -year period. Therefore, government subsidy in both these combinations drastically improves profitability and makes them extremely feasible for farmers.

\section{CONCLUSION}

The study concluded that the yield in all the density combinations of these high-density apple orchards has increased 2-5 times as compared to traditional orchard systems. In quantitative terms, the yield has increased substantially from just 11.43 tones/hectare in the traditional orchards to 21.76 tonnes/hectare and 49.55 tonnes/hectare in 1100 trees/hectare and 4400 trees/hectare orchard in just the fourth year respectively. While the establishment cost is considerably higher in these high-density orchards posing a challenge for their adoption but the lower break-even year provides early profitability, which lowers the interest cost and leads to early returns. According to the results in the paper, the break-even year for all the orchard-density combinations is just six years, which is lower than 11-12 years of traditional apple orchards (Ahmad, 2013). The Internal Rate of Return is lowest while the Net Present Value is highest for the highest-density orchard (4400trees/hectare), and vice versa. Together read, this orchard combination (4400 trees/hectare) sees a slower return but the overall value of the return is significantly higher than the other orchard density combinations, therefore making it the best investment choice. But the paper finds that only 8.2 percent of farmers have opted for this orchard-combination. Another striking conclusion of the paper is that the government support has tremendously increased both the Net Present Value as well as the Internal Rate of Return, of the two orchard combinations (2200 trees/hectare and 3300 trees/hectare). It has also lowered down the break-even year to just 4-5 years, therefore 87.05 percent of farmers start earning net profits earlier than expected. The paper concludes that the government provides crucial support for the establishment of these orchards in Jammu \& Kashmir. The need is to broaden the reach of the scheme with proper support/subsidy being provided to all the density-combinations, especially the highest-density orchard combination. Also, considering that more than three-fourth $\left(3 / 4^{\text {th }}\right)$ of the farmers possess small and marginal farms, government subsidy and support are extremely important to nudge the farmers of the region to this highprofitability scheme.

Funding: This study did not receive any specific financial support.

Competing Interests: The authors declared that they have no conflict of interests.

Contributors/Acknowledgement: All authors participated equally in designing and estimation of current research.

Views and opinions expressed in this study are the views and opinions of the authors, Asian Journal of Agriculture and Rural Development shall not be responsible or answerable for any loss, damage or liability, etc. caused in relation to/arising out of the use of the content. 


\section{Reference}

Ahmad, N. (2013). Problems and prospects of temperate fruits and nut production scenario in India vis-à-vis international scenario. Central Institute of Temperate Horticulture. India

Badiu, D., Arion, F. H., Muresan, I. C., Lile, R., \& Mitre, V. (2015). Evaluation of economic efficiency of apple orchard investments. Sustainability, 7(8), 10521-10533. doi.org/10.3390/su70810521.

Cahn, M. B., \& Goedegebure, J. (1992). Economic aspects of apple production in relation to tree density. New Zealand Journal of Crop and Horticultural Science, 20(3), 289-296. doi.org/10.1080/01140671.1992.10421770.

Chipanshi, A., Zhang, Y., Kouadio, L., Newlands, N., Davidson, A., Hill, H., Warren, R., Qian, B., Daneshfar, B., Bedard, F. (2015). Evaluation of the integrated Canadian crop yield forecaster (ICCYF) model for in-season prediction of crop yield across the Canadian agricultural landscape. Agricultural and Forest Meteorology, 206, 137-150. doi.org/10.1016/j.agrformet.2015.03.007.

Government of India (2018-19). Horticulture at a Glance, 2018. National Horticultural Board, Ministry of Statistics, Planning and Implementation. India

Government of Jammu and Kashmir (2017a). Economic Survey of Jammu and Kashmir. Department of Finance, Jammu and Kashmir.

Government of Jammu and Kashmir (2017b). Readers' Digest. Department of Finance, Jammu and Kashmir.

Hanan, E. (2015). Entrepreneurship perspective for trade and management of horticulture sector in Kashmir Himalayan valley. International Journal of Social Sciences and Management, 2(3), 284-289. doi.org/10.3126/ijssm.v2i3.12986.

Ivey, I. (1990). High density [pipfruit orchards] offers big savings. Horticulture News (New Zealand).

Jha, G. K., Suresh, A., Punera, B., \& Supriya, P. (2019). Growth of horticulture sector in India: Trends and prospects. Indian Journal of Agricultural Science, 89(2), 314-321.

Kerutagi, M. G., Deshetti, M. B., \& Abhilash, K. (2017). Comparative economics of traditional viz high-density mango cultivation in Karnataka. Asian Journal of Agricultural Extension, Economics \& Sociology, 18(3), 1-12. doi.org/10.9734/ajaees/2017/31837.

Kumar, D., Ahmed, N., \& Verma, M. K. (2012). Studies on high density planting in almond in Kashmir valley. Indian Journal of Horticulture, 69(3), 328-332.

Malik, Z. A. (2013). Assessment of apple production and marketing problems in Kashmir valley. Journal of Economic \& Social Development, 9(1), 152-156.

Malik, Z. A., \& Choure, T. (2014). Horticulture growth trajectory evidences in Jammu and Kashmir (A lesson for apple industry in India). Journal of Business Management \& Social Sciences Research, 3(5), 7-10.

Meland, M. (2005). High density planting systems of European plums-the effect of growth and productivity of three cultivars after nine years. Acta Agriculturae Scandinavica, Section BSoil \& Plant Science, 55(1), 51-57. doi.org/10.1080/09064710510008676.

Naqash, F., Wani, S. A., \& Hamid, N. (2019). Economics of controlled atmosphere storage of apple in Jammu and Kashmir State. Journal of Pharmacognosy and Phytochemistry, 8(2), 308312.

Rather, N. A., Lone, P. A., Reshi, A. A., \& Mir, M. M. (2013). An analytical study on production and export of fresh and dry fruits in Jammu and Kashmir. International Journal of Scientific and Research Publications, 3(2), 1-7.

Robinson, T. L., DeMarree, A. M., \& Hoying, S. A. (2004). An economic comparison of five high density apple planting systems. In VIII International Symposium on Canopy, Rootstocks and Environmental Physiology in Orchard Systems 732, pp. 481-489.

Sansavini, S., Bassi, D., \& Giunchi, L. (1980). Tree efficiency and fruit quality in high-density apple orchards. In Symposium on Research and Development on Orchard and Plantation Systems, pp. 114-136. 
Shaheen, F. A., Wani, S. A., \& Kubrevi, S. S. (2019). The landscape of agro-processing industries in Jammu \& Kashmir. Agricultural Economics Research Review, 32(conf), 175-182.

Shastry, A., Sanjay, H. A., \& Bhanusree, E. (2017). Prediction of crop yield using regression techniques. International Journal of Soft Computing, 12(2), 96-102. doi.org/10.17485/ijst/2016/v9i38/91714.

Singh, R., Vaidya, C. S., \& Saraswat, S. P. (2012). Impact of high-density apple plantation under horticulture in Himachal Pradesh. Agro Economic Research Centre, HP University.

Taili, A. (2014). Dynamics of horticulture in Kashmir, India. International Journal of Current Science, 11, E15-E25. 